\title{
KETEPATGUNAAN BERBAGAI MODEL PENDUGAAN VOLUME POHON JENIS KAYU SIBU (Timonius nitens M.et.P.) DI WILAYAH KECAMATAN MANDOBO, KABUPATEN MERAUKE, PROVINSI PAPUA*) (Efficiently of Tree Volume Estimation Models for Timonius nitens M.et.P. in Mandobo Sub-District, Merauke District, Papua Province)
}

\author{
Oleh/By: \\ Bambang Edy Siswanto ${ }^{1)}$, Djoko Wahjono ${ }^{2}$, Harbagung ${ }^{1)}$, dan/and Rinaldi Imanuddin ${ }^{2)}$ \\ ${ }^{1)}$ Pusat Litbang Hutan Tanaman \\ Jl. Gunung Batu No. 5 Po Box 331; Telp. 0251-631238; Fax 0251-7520005 Bogor 16610 \\ ${ }^{2)}$ Pusat Litbang Hutan dan Konservasi Alam \\ Jl. Gunung Batu No. 5 Po Box 165; Telp. 0251-633234, 7520067; Fax 0251-638111 Bogor \\ *) Diterima : 08 Mei 2006; Disetujui : 16 Mei 2007
}

\begin{abstract}
This study was aimed to get information on results of analysis of deterministic equations that appropriate to construct a tree volume estimation model of Timonius nitens M.et.P. species. There are many kind of equations to construct a tree volume model proposed by scientists. Based on 50 tree sample of Timonius nitens M.et.P. collected from a natural forest of Mandobo Sub-District, Marauke, Papua, analysis of various relationships between tree volume and tree diameter at breast height and height of clearbole resulted that the best equation for a tree volume model was $\operatorname{Ln} V=b_{0}+b_{1} \operatorname{Ln} D+b_{2} \operatorname{Ln} H$ and $\operatorname{Ln} V=b_{0}+b_{1} \operatorname{Ln} D+b_{2}$ $L n^{2} H$. The best equation, by using tree diameter at breast height as a variable only, was $L n V=b_{0}+b_{1}+L n$ $D+b_{2} 1 / D$ when $V$ was tree volume without bark and clearbole, $D$ was tree diameter at breast height with its bark $(\mathrm{cm})$, and $H$ was height of clearbole $(\mathrm{m})$. The suggested equation model for Timonius nitens M.et.P. at the study area was $\operatorname{Ln} V=8.25161+1.88855 \mathrm{Ln} D+0.47947 \mathrm{Ln} H$ and $\operatorname{Ln} V=-3.31031+1.17152 \mathrm{Ln} D$ $-35.92390 / D$.
\end{abstract}

Key words: Tree volume models, Timonius nitens M.et.P.

\begin{abstract}
ABSTRAK
Penelitian ini bertujuan untuk memperoleh informasi tentang hasil kajian bentuk-bentuk persamaan deterministik yang cocok untuk penyusunan model pendugaan volume batang jenis kayu sibu (Timonius nitens M.et.P.). Banyak bentuk persamaan yang diajukan para peneliti dalam penyusunan model volume pohon. Didasarkan data 50 pohon sampel Timonius nitens M.et.P. dari hutan alam di wilayah Kecamatan Mandobo, Kabupaten Merauke, Provinsi Papua, analisis berbagai bentuk hubungan antara volume pohon dengan diameter setinggi dada dan tinggi batang bebas cabang membuktikan bahwa bentuk persamaan yang paling cocok dipergunakan sebagai model volume pohon adalah $\mathrm{Ln} \mathrm{V}=\mathrm{b}_{0}+\mathrm{b}_{1} \mathrm{Ln} \mathrm{D}+\mathrm{b}_{2} \operatorname{Ln} \mathrm{H}$ dan $\operatorname{Ln} \mathrm{V}$ $=\mathrm{b}_{0}+\mathrm{b}_{1} \mathrm{Ln} \mathrm{D}+\mathrm{b}_{2} \mathrm{Ln}^{2} \mathrm{H}$; sedangkan bentuk persamaan yang paling cocok apabila hanya didasarkan diameter setinggi dada sebagai peubah penduga adalah $\mathrm{Ln} \mathrm{V}=\mathrm{b}_{0}+\mathrm{b}_{1} \mathrm{Ln} \mathrm{D}+\mathrm{b}_{2}$ 1/D; di mana $\mathrm{V}$ adalah volume batang bebas cabang tanpa kulit $\left(\mathrm{m}^{3}\right)$, D adalah diameter setinggi dada dengan kulit $(\mathrm{cm})$, dan $\mathrm{H}$ adalah tinggi batang bebas cabang $(\mathrm{m})$. Bentuk persamaan yang disarankan sebagai model penduga volume Timonius nitens M.et.P. di lokasi penelitian adalah $\mathrm{Ln} \mathrm{V}=8,25161+1,88855 \mathrm{Ln} \mathrm{D}+0,47947 \mathrm{Ln} \mathrm{H}$ dan Ln $\mathrm{V}=-3,31031+1,17152$ Ln D - 35,92390/D.
\end{abstract}

Kata kunci: Model volume pohon, Timonius nitens M.et.P.

\section{PENDAHULUAN}

Dalam penyusunan rencana pengelolaan hutan, diperlukan data potensi massa tegakan. Dugaan potensi massa tegakan dihitung melalui penjumlahan dugaan volume masing-masing pohon penyusun tegakan yang bersangkutan, berdasarkan data dimensi pohon per pohon yang diukur pada saat pelaksanaan inventarisasi hutan. Sehubungan dengan itu, ketersediaan perangkat pendugaan volume pohon (baik berupa tabel atau model 
persamaan) mutlak diperlukan dalam kegiatan pengelolaan hutan (Spurr, 1952).

Dalam lawas pengelolaan hutan, perangkat pendugaan volume pohon mempunyai posisi strategis sehingga perangkat tersebut dituntut harus akurat. Perangkat pendugaan volume pohon yang tidak akurat akan menyebabkan informasi mengenai potensi massa tegakan yang dihasilkan under-estimate atau over-estimate. Apabila dugaan potensi massa tegakan under-estimate, maka kegiatan pemanenan yang dilaksanakan berlangsung kurang optimal dalam arti tidak memanfaatkan potensi kayu yang ada secara penuh, sebaliknya apabila over-estimate, maka pelaksanaan pemanenan dapat over-cutting atau melebihi batas pemanfaatan kayu yang diperkenankan, yang pada akhirnya dapat mengancam aspek kelestarian hutan. Untuk memperoleh perangkat pendugaan volume pohon yang akurat, maka perangkat tersebut harus disusun mengikuti kaidah-kaidah tertentu, baik di dalam pengumpulan data, pengolahan/analisis data, maupun cara penyajiannya (Husch, 1963).

Oleh karena bentuk batang pohon seringkali beragam menurut jenis atau kelompok jenis dan kondisi tempat tumbuh (site spesific), maka guna memperoleh tingkat keakuratan dugaan yang tinggi, model volume pohon perlu disusun untuk jenis atau kelompok jenis tertentu di setiap unit pengelolaan hutan.

Penelitian ini bertujuan untuk memperoleh informasi tentang hasil kajian bentuk-bentuk persamaan deterministik yang cocok untuk penyusunan model pendugaan volume batang jenis kayu sibu (Timonius nitens M.et.P.) pada hutan alam di wilayah Kecamatan Mandobo, Kabupaten Merauke, Provinsi Papua. Timonius nitens merupakan jenis yang termasuk dalam famili Rubiaceae (Whitmore et al., 1989). Kayu jenis ini mempunyai rata-rata berat jenis 0,72, mempunyai Kelas Awet IV-V dan Kelas Kuat II, sehingga dapat dimanfaatkan untuk bahan bangunan (Seng, 1964). Selain dijual bebas di dalam negeri, kayu jenis ini dimanfaatkan juga untuk diekspor.

Didasarkan pada data 50 pohon sampel yang terkumpul, analisis berbagai bentuk persamaan berhasil mendeteksi beberapa persamaan yang cukup saksama, baik menggunakan dua parameter penduga, yaitu diameter setinggi dada dan tinggi batang bebas cabang, maupun hanya menggunakan satu parameter penduga, yaitu diameter setinggi dada.

\section{RISALAH DAERAH PENELITIAN}

\section{A. Lokasi}

Pohon-pohon sampel dikumpulkan dari hutan alam yang terletak dalam Kelompok Hutan Sungai Mapi-Sungai Digul. Secara geografis hutan tersebut terletak antara $139^{\circ} 52^{\prime}-140^{\circ} 18^{\prime}$ Bujur Timur (BT) dan $5^{\circ} 10^{\prime}-5^{\circ} 51^{\prime}$ Lintang Selatan (LS). Secara administrasi pemerintahan, lokasi penelitian termasuk dalam wilayah Kecamatan Mandobo, Kabupaten Merauke, Provinsi Papua.

\section{B. Topografi, Iklim, dan Jenis Tanah}

Lokasi penelitian terletak pada ketinggian $\pm 130 \mathrm{~m}$ dpl., dengan topografi datar (lereng kurang dari $8 \%$ ). Menurut klasifikasi iklim Schmidt dan Ferguson (1951), iklim di wilayah Kecamatan Mandobo termasuk tipe A dengan ratarata curah hujan $4.500 \mathrm{~mm} /$ th. Berdasar data stasiun pengamatan curah hujan terdekat (di Tanah Merah), curah hujan tertinggi terjadi pada bulan November (333,8 mm), dan curah hujan terendah terjadi pada bulan Juni (176,8 mm). Jumlah hari hujan relatif merata sepanjang tahun, yaitu antara 11-20 hari tiap bulan. Suhu udara relatif tinggi sepanjang tahun, yaitu berkisar antara $24,9^{\circ}-27,5^{\circ} \mathrm{C}$ dengan rata-rata $26,5^{\circ} \mathrm{C}$; sedangkan kelembaban udara berkisar 78,3 \%-88,0 \% dengan rata-rata 82,9 \%. Menurut Peta Tanah Provinsi Irian Jaya (skala 1:1.000.000), tanah di lokasi penelitian memiliki 
formasi batuan alluvium undak dan terumbu koral, termasuk jenis podsolik merah kuning.

\section{Vegetasi}

Lokasi pengumpulan data terletak pada kawasan hutan tanah kering dengan tipe vegetasi hutan tropika basah. Secara umum, hutan di wilayah setempat didominasi oleh jenis kayu cina (Podocarpus neriifolius D.Don.), kayu sibu (Timonius nitens M.et.P.), resak (Vatica rasak (Korth.)Bl.), mersawa (Anisoptera spp.), nyatoh (Palaquium spp.), pulai (Alstonia spp.), matoa (Pometia pinnata J.R.Forster \& J.G.Forster), dan terentang (Campnosperma spp.).

\section{METODE PENELITIAN}

\section{A. Pengumpulan Data}

\section{Pemilihan pohon sampel}

Timonius nitens dipilih sebagai obyek penelitian dengan pertimbangan jenis tersebut merupakan jenis dominan di lokasi penelitian, dan pada saat penelitian jenis tersebut cukup banyak ditebang oleh perusahaan. Pemilihan pohon sampel dilaksanakan secara sengaja (purposive) agar diameter menyebar dari kecil sampai terbesar (diameter $20 \mathrm{~cm}$ ke atas).

\section{Pengukuran pohon sampel}

Pada setiap pohon sampel dilakukan pengukuran diameter setinggi dada $(1,30$ $\mathrm{m}$ di atas tanah, atau $20 \mathrm{~cm}$ di atas banir pada pohon yang berbanir lebih dari 1,10 meter di atas tanah), tinggi batang bebas cabang, dan tinggi pohon (sampai pucuk). Setelah pohon sampel ditebang, dilakukan pengukuran tinggi tonggak dan pembuatan seksi-seksi di sepanjang batang utama dengan panjang seksi satu meter. Pada setiap pangkal dan ujung seksi dilakukan pengukuran diameter dan pengukuran tebal kulit.

Dalam penelitian ini pengukuran volume kayu dibatasi pada batang utama mengingat perusahaan hanya memanen bagian tersebut. Spurr (1952) menyatakan bahwa bagian terpenting dari pohon yang dimanfaatkan kayunya adalah batang pokoknya; namun pada banyak kasus pemanfaatan aktual dari batang pohon sangat beragam dari daerah ke daerah, dari operasi ke operasi, dan dari waktu ke waktu.

\section{B. Analisis Data}

\section{Hubungan tinggi dengan diameter pohon}

Dalam penelitian model pendugaan volume pohon, bentuk hubungan tinggi dengan diameter pohon perlu disajikan dalam rangka menggambarkan sebaran data yang digunakan. Dalam penelitian ini bentuk hubungan tinggi batang bebas cabang dengan diameter setinggi dada disusun melalui analisis regresi linier bentuk Persamaan (1).

$$
\text { Ln } \mathrm{H}=\mathrm{b}_{0}+\frac{\mathrm{b}_{1}}{\mathrm{D}}
$$

dimana:

$\mathrm{H} \quad$ : tinggi batang bebas cabang (clearbole height) (m)

D : diameter setinggi dada dengan kulit (diameter outside bark at breast height) (cm)

$\mathrm{b}_{0}, \mathrm{~b}_{1}$ : koefisien regresi (regression coefficient)

\section{Volume pohon sampel}

Volume pohon sampel dihitung dengan menjumlahkan volume seksi-seksi batang yang merupakan bagian dari pohon sampel yang bersangkutan (Persamaan 4). Volume tiap seksi dihitung menggunakan rumus Smalian yang oleh Chapman dan Meyer (1949); Spurr (1952); Husch (1963); Loetsch et al. (1973); Anonimous (1992); serta Avery dan Burkhart (1994) ditulis dalam bentuk Persamaan (2).

$$
\begin{aligned}
& \mathrm{V}=\frac{\mathrm{B}+\mathrm{b}}{2} \mathrm{~L} \ldots \ldots \ldots \ldots \ldots \ldots \ldots \ldots \ldots \ldots \ldots \ldots \\
& \mathrm{V}_{\mathrm{kl}}=\frac{\pi\left(\mathrm{D}_{\mathrm{kl}}{ }^{2}+\mathrm{d}_{\mathrm{kl}}{ }^{2}\right)}{80000} \mathrm{~L}_{\mathrm{kl}} \\
& \mathrm{V}_{\mathrm{k}}=\sum_{\mathrm{l}=1}^{\mathrm{q}_{\mathrm{k}}} \mathrm{v}_{\mathrm{kl}}
\end{aligned}
$$


dimana:

$\mathrm{v}$ : volume seksi batang (volume of logsection) $\left(\mathrm{m}^{3}\right)$

B : luas bidang dasar pangkal seksi batang (area at the large end of log-section) $\left(\mathrm{m}^{2}\right)$

b : luas bidang dasar ujung seksi batang (area at the small end of log-section) $\left(\mathrm{m}^{2}\right)$

$\mathrm{L}$ : panjang seksi batang (length of logsection) (m)

$\mathrm{v}_{\mathrm{kl}}$ : volume seksi batang ke-l pada pohon sampel ke- $k$ (volume of the $l^{\text {th }} \log$-section of the $k^{\text {th }}$ sample tree) $\left(\mathrm{m}^{3}\right)$

$\mathrm{D}_{\mathrm{kl}}$ : diameter pangkal seksi batang ke-l pada pohon sampel ke-k (diameter at the large end of the $l^{\text {th }} \log$-section of the $k^{\text {th }}$ sample tree) $(\mathrm{cm})$

$\mathrm{d}_{\mathrm{kl}}$ : diameter ujung seksi batang ke-l pada pohon sampel ke-k (diameter at the small end of the $l^{\text {th }} \log$-section of the $k^{\text {th }}$ sample tree) $(\mathrm{cm})$

$\mathrm{L}_{\mathrm{kl}} \quad$ : panjang seksi batang ke-l pada pohon sampel ke-k (length of the $l^{\text {th }}$ log-section of the $k^{\text {th }}$ sample tree) $(\mathrm{m})$

$\mathrm{V}_{\mathrm{k}}$ : volume batang bebas cabang tanpa kulit pohon sampel ke-k (clearbole volume of the $k^{\text {th }}$ sample tree $)\left(\mathrm{m}^{3}\right)$

$\mathrm{q}_{\mathrm{k}} \quad$ : jumlah seksi pada pohon sampel ke-k (log section number of the $k^{\text {th }}$ sample tree)

\section{Model pendugaan volume pohon}

Model pendugaan volume batang bebas cabang disusun dengan cara regresi, yaitu kelompok pertama adalah volume dinyatakan sebagai fungsi dari diameter setinggi dada dan tinggi batang bebas cabang, sedangkan kelompok kedua adalah volume dinyatakan sebagai fungsi dari diameter setinggi dada. Penyederhanaan pendugaan volume yang hanya didasarkan pada satu parameter penduga (Kelompok 2) akan lebih memudahkan kegiatan praktek lapangan, karena pada umumnya pengukuran tinggi pohon sering sulit dilakukan, dan hasil pengukurannya pun sering kurang akurat, serta menyita waktu yang cukup banyak.

Dalam penelitian ini dikaji berbagai model linier yang diajukan oleh Loetsch, Zohrer, dan Haller (1973), yaitu:

a. Kelompok 1: $V=f(D, H)$

$$
\begin{aligned}
\mathrm{V} & =\mathrm{b}_{0} \mathrm{D}^{2} \mathrm{H} \\
\mathrm{V}= & \mathrm{b}_{0}+\mathrm{b}_{1} \mathrm{D}^{2} \mathrm{H} \\
\mathrm{V}= & \mathrm{b}_{0} \mathrm{D}^{2}+\mathrm{b}_{1} \mathrm{D}^{2} \mathrm{H} \\
\mathrm{V}= & \mathrm{b}_{0}+\mathrm{b}_{1} \mathrm{D}^{2}+\mathrm{b}_{2} \mathrm{D}^{2} \mathrm{H}+ \\
& \mathrm{b}_{3} \mathrm{H}
\end{aligned}
$$

$$
\begin{aligned}
\mathrm{V}= & \mathrm{b}_{0} \mathrm{D}^{2}+\mathrm{b}_{1} \mathrm{D}^{2} \mathrm{H}+\mathrm{b}_{2} \mathrm{DH}^{2}+ \\
& \mathrm{b}_{3} \mathrm{H}^{2} \\
\mathrm{~V}= & \mathrm{b}_{0}+\mathrm{b}_{1} \mathrm{D}+\mathrm{b}_{2} \mathrm{D}^{2}+\mathrm{b}_{3} \mathrm{DH}+ \\
& \mathrm{b}_{4} \mathrm{D}^{2} \mathrm{H}+\mathrm{b}_{5} \mathrm{H} \\
\mathrm{V}= & \mathrm{b}_{0}+\mathrm{b}_{1} \mathrm{D}+\mathrm{b}_{2} \mathrm{D}^{2}+\mathrm{b}_{3} \mathrm{DH}+ \\
& \mathrm{b}_{4} \mathrm{D}^{2} \mathrm{H} \\
\mathrm{Ln} \mathrm{V}= & \mathrm{b}_{0}+\mathrm{b}_{1} \mathrm{Ln} \mathrm{D}+ \\
& \mathrm{b}_{2} \mathrm{Ln} \mathrm{H}
\end{aligned}
$$

Ln $\mathrm{V}=\mathrm{b}_{0}+\mathrm{b}_{1} \operatorname{Ln} \mathrm{D}^{2} \mathrm{H}$ (13)

$$
\begin{gathered}
\operatorname{Ln} V=b_{0}+b_{1} \operatorname{Ln} \mathrm{D}+\mathrm{b}_{2} \operatorname{Ln}^{2} \mathrm{D}+ \\
\mathrm{b}_{3} \operatorname{Ln} \mathrm{H}+\mathrm{b}_{4} \operatorname{Ln}^{2} \mathrm{H}
\end{gathered}
$$

b. Kelompok 2: $V=f(D)$

$$
\begin{aligned}
& \mathrm{V}=\mathrm{b}_{0}+\mathrm{b}_{1} \mathrm{D}^{2} \\
& \mathrm{~V}=\mathrm{b}_{0} \mathrm{D}+\mathrm{b}_{1} \mathrm{D}^{2} \\
& \mathrm{~V}=\mathrm{b}_{0}+\mathrm{b}_{1} \mathrm{D}+\mathrm{b}_{2} \mathrm{D}^{2} \\
& \mathrm{Ln} \mathrm{V}=\mathrm{b}_{0}+\mathrm{b}_{1} \operatorname{Ln} \mathrm{D} \\
& \text { Ln } \mathrm{V}=\mathrm{b}_{0}+\mathrm{b}_{1} \operatorname{Ln} \mathrm{D}+\mathrm{b}_{2} \frac{1}{\mathrm{D}}
\end{aligned}
$$

dimana:

$\mathrm{V}$ : volume batang bebas cabang tanpa kulit (clearbole volume without bark) $\left(\mathrm{m}^{3}\right)$

$\mathrm{D}$ : diameter setinggi dada dengan kulit (diameter outside bark at breast height) $(\mathrm{cm})$

$\mathrm{H}$ : tinggi batang bebas cabang (clearbole height) $(\mathrm{m})$

$\mathrm{b}_{0}, \mathrm{~b}_{1}, \mathrm{~b}_{2}, \mathrm{~b}_{3}, \mathrm{~b}_{4}, \mathrm{~b}_{5}$ : koefisien regresi (regression coefficient)

\section{Tolok ukur keakuratan persamaan}

Tingkat kecocokan persamaan dalam menggambarkan volume batang bebas cabang pohon kayu sibu di wilayah Kecamatan Mandobo, Kabupaten Merauke, Provinsi Papua diukur dari besarnya koefisien determinasi (determination coefficient- $\mathrm{R}^{2}$ ), serta kecilnya simpangan agregatif (aggregate difference-AD), dan rataan persentase simpangan (average percentage deviation-APD). Koefisien determinasi yang mendekati satu menunjukkan bahwa peubah-peubah tidak bergantung yang tercantum dalam persamaan dapat menerangkan keragaman peubah bergantung secara hampir sempurna.

Simpangan agregatif (AD) ialah besarnya perbedaan antara nilai dugaan dengan volume aktual secara agregat; sedangkan rataan persentase simpangan (APD) menyatakan besarnya perbedaan antara nilai dugaan dengan volume aktual secara rata- 
rata dari masing-masing individu pohon sampel. Nilai AD dan APD dihitung dengan menggunakan rumus Bruce dalam Husch (1963) sebagaimana bentuk Persamaan (20) dan Persamaan (21). Spurr (1952) dan Husch (1963) menyatakan bahwa sebaiknya nilai AD tidak lebih kecil dari $-1 \%$ dan tidak lebih besar dari 1 $\%$; dan nilai APD tidak lebih dari $8 \%$.

$$
\begin{aligned}
& \mathrm{AD}=\frac{\sum \mathrm{Y}-\sum \mathrm{f}(\mathrm{x})}{\sum \mathrm{Y}} \times 100 \% \\
& \mathrm{APD}=\frac{\sum\left|\frac{\mathrm{Y}-\mathrm{f}(\mathrm{x})}{\mathrm{Y}}\right|}{\mathrm{N}} \times 100 \% .
\end{aligned}
$$

dimana:

$\mathrm{AD}$ : simpangan agregatif (aggregate difference)

APD : rataan persentase simpangan (average percentage deviation)

$\mathrm{Y}$ : nilai aktual (actual value)

$\mathrm{f}(\mathrm{x})$ : nilai dugaan (prediction value)

$\mathrm{N}$ : jumlah pengamatan (observation number)

\section{HASIL DAN PEMBAHASAN}

\section{A. Cakupan Data}

Jumlah pohon sampel yang digunakan dalam penelitian ini adalah 50 pohon dengan cakupan data diameter setinggi dada terkecil $22 \mathrm{~cm}$ dan terbesar $69 \mathrm{~cm}$; sedangkan tinggi batang bebas cabang terpendek $12 \mathrm{~m}$ dan tertinggi $23 \mathrm{~m}$. Gambaran sebaran pohon sampel menurut diameter dan tinggi batang bebas cabang dapat dilihat pada Gambar 1.

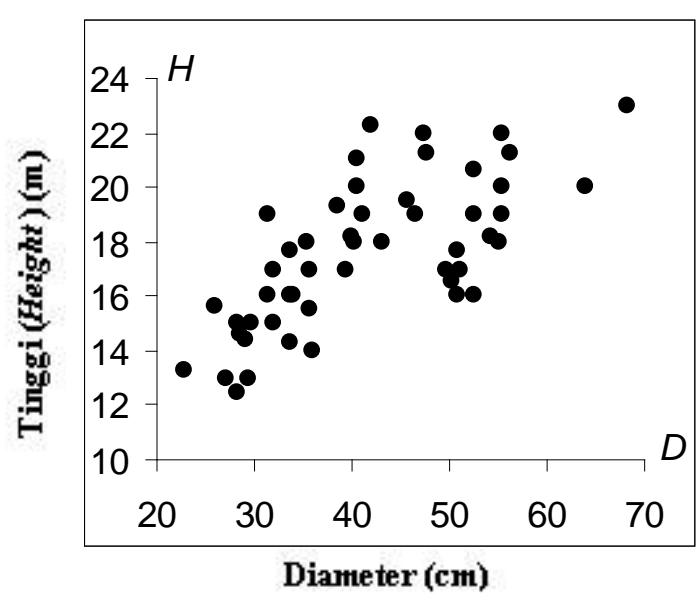

Gambar (Fig) 1. Sebaran pohon sampel menurut diameter setinggi dada dan tinggi batang bebas cabang (Sample trees distribution according to diameter at breast height and clearbole height)

Hasil analisis regresi hubungan tinggidiameter dengan dasar bentuk Persamaan (1) adalah Persamaan (22). Koefisien determinasi persamaan tersebut adalah sebesar 0,544 .

$$
\text { Ln } \mathrm{H}=3,28384-\frac{16,7343}{\mathrm{D}}
$$

dimana:

$\mathrm{H}$ : tinggi batang bebas cabang (clearbole height) (m)

$\mathrm{D}$ : diameter setinggi dada dengan kulit (diameter at breast height) (cm)

\section{B. Model Volume dengan Parameter Penduga Diameter dan Tinggi}

Dari data volume 50 pohon sampel yang terkumpul, hasil perhitungan koefisien regresi yang diperoleh dari analisis regresi linier berdasarkan bentuk Persamaan (5) sampai dengan Persamaan (14) secara rinci dirangkum dalam Tabel 1.

Hasil analisis regresi menunjukkan bahwa beberapa peubah penduga terbukti tidak berperan secara nyata sampai taraf nyata $5 \%$, sehingga peubah-peubah tersebut harus tidak diikut-sertakan di dalam model, yaitu meliputi:

a. Peubah $\mathrm{D}^{2} \mathrm{H}$ dalam bentuk Persamaan (7), sehingga persamaan ini menjadi model dengan satu parameter penduga (hanya parameter diameter)

b. Peubah-peubah $\mathrm{D}^{2} \mathrm{H}$ dan $\mathrm{H}^{2}$ dalam bentuk Persamaan (9)

c. Peubah-peubah $\mathrm{D}^{2}, \mathrm{DH}$, dan $\mathrm{H}$ dalam bentuk Persamaan (10)

d. Peubah $\mathrm{D}^{2}$ dan Peubah DH dalam bentuk Persamaan (11), sehingga persamaan ini menjadi sama dengan bentuk Persamaan (10)

e. Peubah $\operatorname{Ln}^{2} \mathrm{D}$ dan Peubah Ln H dalam bentuk Persamaan (14).

Dengan adanya beberapa peubah yang harus dikeluarkan dari model sebagaimana telah diterangkan di atas, maka secara rinci hasil persamaan yang sah (secara kaidah statistika) dan tetap mengandung dua parameter penduga (diameter dan tinggi) adalah sebagai berikut: 
$\mathrm{V}=0,00004 \mathrm{D}^{2} \mathrm{H}$

$$
\mathrm{V}=0,23775+0,00003 \mathrm{D}^{2} \mathrm{H}(24)
$$

Tabel (Table) 1. Nilai koefisien regresi model pendugaan volume batang bebas cabang tanpa kulit dengan diameter setinggi dada dan tinggi batang bebas cabang sebagai parameter penduga (The regression coefficient of clearbole without bark volume estimation models with diameter at breast height and clearbole heght as estimator parameters)

\begin{tabular}{|c|c|c|c|c|c|c|c|}
\hline \multirow{2}{*}{$\begin{array}{l}\text { Persamaan } \\
\text { (Equation) }\end{array}$} & \multicolumn{6}{|c|}{ Nilai koefisien regresi (The regression coefficients) } & \multirow{2}{*}{$\begin{array}{l}\text { Keterangan } \\
\text { (Notes) }\end{array}$} \\
\hline & $\mathrm{b}_{0}$ & $\mathrm{~b}_{1}$ & $\mathrm{~b}_{2}$ & $\mathrm{~b}_{3}$ & $\mathrm{~b}_{4}$ & $\mathrm{~b}_{5}$ & \\
\hline (5) & 0,00004 & - & - & - & - & - & \\
\hline (6) & 0,23775 & 0,00003 & - & - & - & - & \\
\hline (7) & 0,00068 & ns & - & - & - & - & \\
\hline (8) & $-0,64249$ & 0,00077 & $-0,00001$ & 0,04331 & - & - & \\
\hline (9) & 0,00056 & ns & 0,00002 & ns & - & - & \\
\hline (10) & $-0,73287$ & 0,03933 & ns & ns & 0,00001 & ns & \\
\hline (11) & $-0,73287$ & 0,03933 & ns & ns & 0,00001 & - & sama (equal) (10) \\
\hline (12) & $-8,25161$ & 1,88855 & 0,47947 & - & - & - & \\
\hline (13) & $-8,64177$ & 0,85288 & - & - & - & - & \\
\hline (14) & $-8,31521$ & 1,88407 & ns & ns & 1,38315 & - & \\
\hline
\end{tabular}

Keterangan (Remark): ns : tidak nyata sampai taraf nyata 5 \% (non significant at significance level .05)

$$
\begin{aligned}
& \mathrm{V}=-0,64249+0,00077 \mathrm{D}^{2}+ \\
& 0,00001 \mathrm{D}^{2} \mathrm{H}+0,04331 \mathrm{H} \\
& \mathrm{V}=0,00056 \mathrm{D}^{2}+0,00002 \mathrm{DH}^{2} \\
& \mathrm{~V}=0,73287+0,03933 \mathrm{D}+ \\
& 0,00001 \mathrm{D}^{2} \mathrm{H} \\
& \text { Ln V = 8,25161 + 1,88855 Ln D + } \\
& 0,47947 \text { Ln H } \\
& 1,38315 \mathrm{Ln}^{2} \mathrm{H}
\end{aligned}
$$

Hasil perhitungan koefisien determinasi $\left(R^{2}\right)$, simpangan agregatif (AD), dan rataan persentase simpangan (APD) Persamaan (23) sampai dengan Persamaan (28) dapat dilihat dalam Tabel 2.

Dalam Tabel 2 terlihat bahwa semua persamaan dapat dikategorikan cukup cermat apabila didasarkan besarnya koefisien determinasi yang cukup tinggi. Persamaan yang mempunyai koefisien determinasi terkecil adalah Persamaan (24) dengan $\mathrm{R}^{2}=0,965$. Hal ini menandakan bahwa dalam masing-masing persamaan, keragaman peubah-peubah bebas yang merupakan berbagai bentuk transformasi diameter dan tinggi, lebih dari 95 $\%$ dapat menerangkan keragaman volume batang bebas cabang tanpa kulit. Namun demikian, dihadapkan pada tolok ukur keakuratan persamaan seperti yang dikemukakan oleh Spurr (1952) dan Husch (1963), Persamaan (23) merupakan persamaan yang tidak layak pakai karena mempunyai simpangan agregatif lebih dari $1 \%$ dan rataan persentase simpangan lebih $8 \%$.

Dari Persamaan (24) sampai Persamaan (30), yaitu persamaan-persamaan yang memenuhi persyaratan $(-1 \% \leq \mathrm{AD} \leq 1 \%$ dan APD $\leq 8 \%$ ), Persamaan (30) dan Persamaan (28) merupakan persamaan yang paling layak dipergunakan karena mempunyai nilai APD paling kecil. Dibandingkan dengan simpangan agregatif (AD), rataan persentase simpangan (APD) dari suatu persamaan dipandang lebih cocok untuk mempertimbangkan keakuratan persamaan karena nilainya lebih mencerminkan besarnya simpangan masing-masing individu data pohon sampel.

Dalam Tabel 2 terlihat bahwa nilai AD dan APD dari Persamaan (28) tidak jauh berbeda dengan Persamaan (30). Sehubungan dengan itu, dengan dasar pertimbangan kesederhanaan bentuk model maka disarankan Persamaan (28) dipilih sebagai model penduga volume batang bebas cabang (tanpa kulit) jenis kayu sibu di lokasi penelitian.

\section{Model Volume dengan Parameter Penduga Diameter}

Dalam analisis regresi model pendugaan volume dengan parameter penduga 
ganda pada Sub-Bab IVB telah disebut-

kan bahwa bentuk Persamaan (7) berubah Tabel (Table) 2. Koefisien determinasi, simpangan agregatif, dan rataan persentase simpangan model pendugaan volume batang bebas cabang tanpa kulit dengan diameter setinggi dada dan tinggi batang bebas cabang sebagai parameter penduga (The determination coefficients$R^{2} \mathrm{~s}$, agregate differences- $A D$ 's, and average percentage deviations-APD's of clearbole without bark volume estimation models with diameter at breast height and clearbole height as estimator parameters)

\begin{tabular}{cccccc}
\hline $\begin{array}{c}\text { Persamaan } \\
\text { (Equations) }\end{array}$ & $\mathrm{R}^{2}$ & $\begin{array}{c}\mathrm{AD} \\
(\%)\end{array}$ & $\begin{array}{c}\mathrm{APD} \\
(\%)\end{array}$ & $\begin{array}{c}\mathrm{APD}_{\max } \\
(\%)\end{array}$ & $\begin{array}{c}\text { Keterangan } \\
(\text { Notes })\end{array}$ \\
\hline$(23)$ & 0,985 & 5,14 & 12,10 & 26,80 & tidak memenuhi syarat (unqualified) \\
$(24)$ & 0,965 & 0,00 & 7,99 & 35,39 & \\
$(25)$ & 0,993 & 0,00 & 3,95 & 20,02 & \\
$(26)$ & 0,998 & $-0,19$ & 4,44 & 26,22 & \\
$(27)$ & 0,993 & 0,00 & 4,16 & 26,91 & \\
$(28)$ & 0,991 & $-0,26$ & 3,69 & 17,13 & \\
$(29)$ & 0,986 & $-0,10$ & 4,98 & 18,08 & \\
$(30)$ & 0,992 & $-0,24$ & 3,63 & 16,56 & \\
\hline
\end{tabular}

menjadi model dengan parameter penduga tunggal (hanya diameter), karena tidak berperannya Peubah- $\mathrm{D}^{2} \mathrm{H}$ di dalam persamaan; dan persamaan yang terbentuk adalah Persamaan (31).

$\mathrm{V}=0,00068 \mathrm{D}^{2}$

Nilai koefisien yang diperoleh dari analisis regresi model pendugaan volume dengan menggunakan diameter sebagai parameter penduga (Kelompok 2: $\mathrm{V}=\mathrm{f}$ (D)) dengan dasar bentuk Persamaan (15) sampai dengan Persamaan (19) dirangkum pada Tabel 3.

Pada Tabel 3 tampak bahwa intersep$\mathrm{b}_{0}$ dalam bentuk Persamaan (15) dan ben-tuk Persamaan (16) tidak berperan secara nyata dan harus dikeluarkan dari model sehingga hasil kedua bentuk persamaan tersebut tidak berbeda dengan Persamaan (31). Dengan demikian analisis regresi terhadap bentuk-bentuk model pendugaan volume dengan parameter penduga dia-meter hanya menghasilkan tiga persama-an baru, yaitu Persamaan (32) yang ber-asal dari bentuk Persamaan (17), Persa-maan (33) yang berasal dari bentuk Per-samaan (18), dan Persamaan (34) yang berasal dari bentuk Persamaan (19).

$$
\begin{aligned}
& \mathrm{V}=-0,70154+0,03471 \mathrm{D}+ \\
& 0,00028 \mathrm{D}^{2} \ldots \ldots \ldots \ldots \ldots \ldots \ldots \ldots . .(32) \\
& \text { Ln } \mathrm{V}=-7,63521+2,09201 \text { Ln D....(33) }
\end{aligned}
$$

$$
\operatorname{Ln} V=-3,31031+1,17152 \operatorname{Ln} D-\frac{35,92390}{D}
$$

Hasil perhitungan koefisien determinasi $\left(R^{2}\right)$, simpangan agregatif (AD), dan rataan persentase simpangan (APD) Persamaan (31) sampai dengan Persamaan (34) dapat dilihat dalam Tabel 4.

Dalam Tabel 4 terlihat bahwa Persamaan (34) mempunyai rataan persentase simpangan terkecil (dibandingkan dengan persamaan lainnya) sehingga persamaan tersebut merupakan model yang paling layak untuk dikembangkan menjadi perangkat pendugaan volume batang bebas cabang jenis kayu sibu pada hutan alam di wilayah Kecamatan Mandobo, Kabupaten Merauke, Provinsi Papua.

Dengan mempertimbangkan segi kepraktisan penggunaannya di lapangan, maka model persamaan dengan parameter penduga tunggal yaitu diameter (Persamaan 34) dianggap paling tepat untuk digunakan karena sudah memenuhi kriteria ketelitian dan keakuratan yang disyaratkan. Penggunaan Persamaan (34) tersebut hanya mengurangi tingkat keakuratan (yang tercermin dari nilai APD) tidak lebih dari 1,42 \% dan tingkat ketelitian (tercermin dari nilai $\mathrm{R}^{2}$ ) tidak lebih dari 0,5 \% dibandingkan dengan menggunakan model persamaan dengan parameter penduga ganda yaitu diameter dan tinggi pohon (Persamaan 28 dan 30). 

Tabel (Table) 3. Nilai koefisien regresi model pendugaan volume batang bebas cabang tanpa kulit dengan diameter setinggi dada sebagai parameter penduga (The regression coefficient of clearbole without bark volume estimation models with diameter at breast height as estimator parameter)

\begin{tabular}{|c|c|c|c|c|}
\hline \multirow{2}{*}{$\begin{array}{l}\text { Persamaan } \\
\text { (Equation) }\end{array}$} & \multicolumn{3}{|c|}{ Nilai koefisien regresi (The regression coefficients) } & \multirow{2}{*}{$\begin{array}{c}\text { Keterangan } \\
\text { (Notes) }\end{array}$} \\
\hline & $\mathrm{b}_{0}$ & $\mathrm{~b}_{1}$ & $\mathrm{~b}_{2}$ & \\
\hline (15) & ns & 0,00068 & - & sama (equal) (31) \\
\hline (16) & ns & 0,00068 & - & sama (equal) (31) \\
\hline$(17)$ & $-0,70154$ & 0,03471 & 0,00028 & \\
\hline (18) & $-7,63521$ & 2,09201 & - & \\
\hline (19) & $-3,31031$ & 1,17152 & $-35,92390$ & \\
\hline
\end{tabular}

Keterangan (Remark): ns : tidak nyata sampai taraf nyata 5 \% (non significant at significance level .05)

Tabel (Table) 4. Koefisien determinasi, simpangan agregatif, dan rataan persentase simpangan model pendugaan volume batang bebas cabang tanpa kulit dengan diameter setinggi dada sebagai parameter penduga (The determination coefficients- $R^{21} \mathrm{~s}$, agregate differences$A D$ 's, and average percentage deviations-APD's of clearbole without bark volume estimation models with diameter at breast height as estimator parameters)

\begin{tabular}{cccccc}
\hline $\begin{array}{c}\text { Persamaan } \\
\text { (Equations) }\end{array}$ & $\mathrm{R}^{2}$ & $\begin{array}{c}\mathrm{AD} \\
(\%)\end{array}$ & $\begin{array}{c}\text { APD } \\
(\%)\end{array}$ & $\begin{array}{c}\text { APD }_{\max } \\
(\%)\end{array}$ & $\begin{array}{c}\text { Keterangan } \\
(\text { Notes })\end{array}$ \\
\hline$(31)$ & 0,997 & 0,28 & 5,98 & 29,62 & \\
$(32)$ & 0,989 & 0,00 & 5,32 & 26,95 & \\
$(33)$ & 0,983 & $-0,27$ & 5,74 & 24,21 & \\
$(34)$ & 0,987 & 0,10 & 5,05 & 19,76 & \\
\hline
\end{tabular}

\section{KESIMPULAN DAN SARAN}

\section{A. Kesimpulan}

1. Dari analisis berbagai bentuk persamaan, bentuk Ln $\mathrm{V}=\mathrm{b}_{0}+\mathrm{b}_{1} \operatorname{Ln} \mathrm{D}+$ $\mathrm{b}_{2} \operatorname{Ln} \mathrm{H}$ dan $\operatorname{Ln} \mathrm{V}=\mathrm{b}_{0}+\mathrm{b}_{1} \operatorname{Ln} \mathrm{D}+\mathrm{b}_{2}$ $\mathrm{Ln}^{2} \mathrm{H}$ dapat dijadikan dasar penyusunan model pendugaan volume batang bebas cabang tanpa kulit jenis kayu sibu (Timonius nitens M.et.P.) pada hutan alam di wilayah Kecamatan Mandobo, Kabupaten Merauke, Provinsi Papua. Secara rinci persamaanpersamaan tersebut adalah:

$$
\begin{aligned}
\text { Ln } \mathrm{V}= & 8,25161+1,88855 \operatorname{Ln} \mathrm{D}+ \\
& 0,47947 \operatorname{Ln} \mathrm{H} \\
\mathrm{Ln} \mathrm{V}= & 8,31521+1,88407 \mathrm{Ln} \mathrm{D}+ \\
& 1,38315 \mathrm{Ln}^{2} \mathrm{H}
\end{aligned}
$$

di mana $\mathrm{V}$ adalah volume batang bebas cabang tanpa kulit $\left(\mathrm{m}^{3}\right)$, D adalah diameter setinggi dada dengan kulit (cm), dan $\mathrm{H}$ adalah tinggi batang bebas cabang (m).
2. Didasarkan penggunaan diameter setinggi dada sebagai parameter penduga tunggal, bentuk persamaan $\mathrm{Ln} \mathrm{V}=\mathrm{b}_{0}$ $+b_{1}$ Ln D + $b_{2}$ 1/D merupakan persamaan yang paling layak dipergunakan. Perhitungan koefisien regresi dari bentuk persamaan tersebut menghasilkan persamaan sebagai berikut:

Ln $\mathrm{V}=-3,31031+1,17152 \operatorname{Ln} \mathrm{D}-\frac{35,92390}{\mathrm{D}}$ di mana $\mathrm{V}$ adalah volume batang bebas cabang tanpa kulit $\left(\mathrm{m}^{3}\right)$, D adalah diameter setinggi dada dengan kulit (cm).

3. Dari segi kepraktisannya, model persamaan dengan parameter penduga tunggal (butir 2) tersebut paling tepat digunakan dalam menduga volume batang bebas cabang tanpa kulit jenis kayu sibu (Timonius nitens M.et.P.) pada hutan alam di wilayah Kecamatan Mandobo, Kabupaten Merauke, Provinsi Papua. 


\section{B. Saran}

1. Agar praktis dalam penggunaannya di lapangan, persamaan-persamaan dalam butir kesimpulan di atas sebaiknya dijabarkan dalam bentuk tabel volume.

2. Guna mendapatkan kesimpulan beberapa bentuk persamaan yang paling luwes untuk digunakan dalam penyusunan model pendugaan volume pohon, penelitian serupa perlu direplikasi untuk banyak jenis di berbagai lokasi.

\section{DAFTAR PUSTAKA}

Anonimous. 1992. Manual Kehutanan. Departemen Kehutanan Republik Indonesia. Jakarta.

Avery, T.E. and H.E. Burkhart. 1994. Forest Measurements. McGraw-Hill Book Company, Inc. New York.

Chapman, H.H. and W.H. Meyer. (1949).

Forest Mensuration. McGraw-Hill Book Company, Inc. New York.
Husch, B. 1963. Forest Mensuration and Statistics. The Ronald Press Company. New York.

Loetsch, F., F. Zohrer, and K.E. Haller. 1973. Forest Inventory. BLV Verlagsgesellschaft. Munchen.

Schmidt, F.H. and J.H.A. Fergusson. 1951. Rainfall Types Based on Wet and Dry Period Ratios for Indonesia with Western New Guinea. Verhand No. 42. Kementrian Perhubungan, Djawatan Meteorologi dan Geofisika, Jakarta.

Seng, O.D. 1964. Berat Jenis dari Jenisjenis Kayu Indonesia dan Pengertian Beratnya Kayu untuk Keperluan Praktek. Pengumuman Nr. 1. Lembaga Penelitian Hasil Hutan. Bogor.

Spurr, S.H. 1952. Forest Inventory. The Ronald Press Company. New York.

Whitmore, T.C., I.G.M. Tantra, and U. Sutisna. 1989. Tree Flora of Indonesia Check List for Sulawesi. Forest Research and Development Centre. Bogor. 